\title{
$\begin{array}{lllllllllllllllll}\mathbf{P} & \mathbf{O} & \mathbf{L} & \mathbf{E} & \mathbf{M} & \mathbf{I} & \mathbf{K} & \mathbf{I} & \mathbf{I} & \mathbf{D} & \mathbf{Y} & \mathbf{S} & \mathbf{K} & \mathbf{U} & \mathbf{S} & \mathbf{J} & \mathbf{E}\end{array}$
}

KWARTALNIK HISTORII KULTURY MATERIALNEJ 67 (1), 2019 PL ISSN 0023-5881

www.iaepan.edu.pl

DOI: 10.23858/KHKM67.2019.1.010

\section{Odpowiedź na recenzję Andrzeja Klondera zamieszczoną w „Kwartalniku HKM” (R. LXVI, 2018, nr 1)}

Z uwagą oraz z dużą satysfakcją odnotowałam kolejną recenzję mojej książki zatytułowanej Homo nobilis. Wzorzec szlachcica w Rzeczypospolitej XVI i XVII wieku, Warszawa 2017 (PWN). Zarówno ta, jak i pozostałe, ukazujące się nie tylko w różnego rodzaju mediach, ale także na łamach znaczących czasopism naukowych, świadczą o ogromnym zainteresowaniu tego rodzaju tematyką. Wszystko to utwierdza mnie w przekonaniu, że jest to praca ważna i potrzebna, że wypełnia istotną lukę w dotychczasowych badaniach i że wreszcie zasadniczo odbiega od utrwalonego w literaturze schematu. Warto przy tym podkreślić, iż każda nowość budzi kontrowersje i prowokuje do polemiki.

W takim kontekście odczytałam recenzję pióra Andrzeja Klondera. Jej Autorowi z jednej strony chcę podziękować za pozytywną ocenę wyrażoną w konkluzji opublikowanej opinii, z drugiej zaś czuję się zobligowana do wyjaśnienia tych kwestii, które wzbudziły wątpliwości piszącego.

Przechodząc do meritum, w pierwszym rzędzie muszę zakwestionować takie sformułowania Recenzenta, z którymi w żadnym razie nie mogę się zgodzić. Należy do nich stwierdzenie, że zagadnienie szlacheckich wzorców osobowych to ,temat dyskutowany w polskiej historii niemal od jej zarania jako dyscypliny naukowej, związany przy tym mocno z wielkim sporem o przyczyny upadku Rzeczypospolitej” (s.111). Być może Andrzej Klonder ma tu na myśli liczne rozważania na temat kondycji szlachty, prowadzone w kontekście kolejnych rozbiorów, ale one nie mają przecież nic wspólnego z ówcześnie lansowanymi standardami natury genealogicznej, osobowościowej, profesjonalnej czy społecznej. Te ostatnie — zgodnie z zaprezentowaną w książce koncepcją — stanowią komponenty postulowanego i akceptowanego, choć nie zawsze realizowanego, wzorca osobowego.

Tak rozumiane wzorce nigdy nie należały i nadal nie należą do głównego nurtu naukowych dociekań. Stosunkowo rzadko pojawiają się prace, które za przedmiot swoich badań biorą przeobrażenia dokonujące się na poziomie umysłowości, mentalności, skupione na aksjologicznych wyznacznikach postępowania jednostki, na teoretycznych drogowskazach, nakierowujących człowieka na właściwy cel i pobudzających do pożądanej aspiracji. Za takie nie można uznać wskazanych przez Recenzenta rozpraw, dotyczących szeroko rozumianych dziejów kultury czy obyczaju, co oczywiście nie umniejsza ich wartości. Do takich nie należy też Szlachta polska i jej państwo Jaremy Maciszewskiego. Wbrew bezpodstawnemu zarzutowi Recenzenta w żadnym razie nie została ona przeze mnie zapomniana. Zawiera przecież szereg ciągle aktualnych ustaleń. Jednak w kwestii wzorców osobowych zasadniczo odbiega od wyników moich badań, co być może należy położyć na karb czasów jej publikacji.

Czytając opinię A. Klondera mam wrażenie, że część zawartych w niej uwag została wywiedziona właśnie $\mathrm{z}$ książki Maciszewskiego. Tego rodzaju zbieżność widoczna jest w podawaniu w wątpliwość wynikających z moich ustaleń lansowanych wówczas standardów menadżerskich, postulatów nowoczesności i postępu i przeciwstawianie ich — zdaniem Recenzenta — rzekomo typowym dla szlachty zacofaniu czy konserwatyzmowi. Wady te w XVII w. miały skutkować kryzysem gospodarki folwarcznej, w czasie którego „postępował upadek kultury 
rolnej, pogarszały się jakość narzędzi, metody uprawy, malały plony” (s.113). Z tak postawioną tezą nie mogę się zgodzić. Przy tym ta niezgoda nie wynika ze stanu faktycznego, bo XVII stulecie to rzeczywiście okres regresu gospodarczego. Tyle tylko, że źródeł tego regresu nie można upatrywać w szlacheckim konserwatyzmie, a w sytuacji Rzeczypospolitej, szarpanej nieustannymi wojnami zewnętrznymi i wewnętrznymi. W czasie każdej wojny nie tylko „milczą muzy", ale, co gorsze, giną ludzie, majątki popadają w ruinę, zostaje zachwiana płynność podatkowa, co skutkuje pustym skarbem. Jak obliczył Jerzy Topolski, zniszczenia, jakich w tym okresie doświadczyło polsko-litewskie państwo, były tak duże, że dopiero po upływie dwustu lat udało się powrócić do stanu wyjściowego ${ }^{1}$. I to jest prawdziwa przyczyna ekonomicznego regresu Rzeczypospolitej i jej elit, a nie rzekome wady stanu szlacheckiego.

Kolejna kwestia, która wymaga komentarza, wiąże się wyrażonym przez Recenzenta poczuciem niedosytu, związanym z brakiem w Homo nobilis informacji na temat staropolskiego obyczaju, zasad funkcjonowania rodziny, opisów etykiety czy ubioru. W tym samym szeregu równie dobrze można by postawić postulat omówienia podstaw folwarcznej ekonomii, struktury urzędniczej i sejmowej, taktyki wojennej, praktyki dyplomatycznej i religijnej, bo przecież piszę o wzorcu gospodarza, urzędnika, posła, żołnierza, dyplomaty i chrześcijanina. Jednak zadośćuczynienie w tym względzie oczekiwaniom historyków kultury materialnej, ustroju, wojskowości czy religii wyklucza już tematyka określona w tytule. Wzorce i związane z nimi standardy dokonują się w sferze mentalnej. Są oderwane od konkretu, który funkcjonuje tu wyłącznie w wymiarze aksjologiczno-symbolicznym i ten wymiar został w pełni uwzględniony. Co więcej, tego rodzaju sfera, w przeciwieństwie do powierzchownego charakteru mody czy polityki, urzeczywistnia się w najgłębszych pokładach dziejów. Stąd też, stosując terminologię Ferdynanda Braudela, cechuje się tzw, „długim trwaniem”. Nie jest więc możliwe, czego oczekuje Recenzent, uchwycenie różnic w kształcie wzorca szlacheckiego na przestrzeni XVI i XVII w., bo takie generalnie nie zachodziły. W tym okresie ten wzorzec w zasadniczym kształcie nie ulega zmianie. Do takiego wniosku, wśród wielu innych, prowadzi analiza źródeł dokonana na stronach Homo nobilis, wyraźnie zresztą wyartykułowana.

W recenzji znalazły się także uwagi na temat doboru źródeł. Jak zauważył Andrzej Klonder, na przydatność staropolskich zwierciadeł w badaniach nad wzorcami osobowymi, co także zostało odnotowane w mojej książce, wskazywał już Janusz Tazbir². Tego rodzaju źródła zostały w rozprawie wykorzystane. Za istotne ich uzupełnienie uznałam rozmaite poradniki (rolnicze, dyplomatyczne), które wzbudziły wątpliwości Recenzenta. W przypadku Homo nobilis są one jednak w pełni uzasadnione. Przesądza o tym moja koncepcja struktury wzorców, która zawiera istotny dla nich komponent, dotąd nie dostrzegany, w postaci uwarunkowań profesjonalnych.

Profesjonalizm w oczywisty sposób wiąże się z profesją. Tak określiłam różne formy szlacheckiej aktywności na polu ekonomicznym, politycznym, urzędniczym, żołnierskim czy dyplomatycznym. W tym miejscu pozwolę sobie nie zgodzić się z sugestią Recenzenta, który termin profesja uważa za nieprzystający do ról podejmowanych przez szlachtę. Moje stanowisko w tej sprawie wyjaśniam zresztą w książce (s. 124). Mimo to czuję się zobligowana do ponownego wskazania na fakt, że po pierwsze, pojęcie profesji funkcjonowało w epoce staropolskiej, m.in. w twórczości Łukasza Górnickiego ${ }^{3}$, po drugie zaś, nawet patrząc $z$ dzisiejszej perspektywy, przez profesjonalizm rozumiemy znawstwo i specjalizację. Takich cech oczekiwano wówczas od wzorców i wzorów osobowych.

\footnotetext{
1 Topolski J. 1977, s. 64.

2 Tazbir J. 1976, z. 4, s. 784-797.

3 Górnicki Ł. 1954, s. 49.
} 
Przy tematyce szlacheckich profesji warto odnieść się jeszcze do wzorca dworzanina. Recenzent wskazuje tu - idąc tropem wcześniejszych ustaleń — że ten ostatni nie doczeka1 się „,masowej akceptacji i realizacji” (s. 111). Nie wspomniał o moim stanowisku w tej sprawie, które zostało w książce wyraźnie odnotowane (s. 187-188). Stąd też pozwolę sobie zaznaczyć, że taki wzorzec funkcjonował, ale nie jako byt samoistny, lecz jako forma aneksu przypisanego do innych wzorców. Dworność bowiem to integralna część wzorca gospodarza, urzędnika, parlamentarzysty, żołnierza i dyplomaty. Bez tej cnoty żaden z wyżej wymienionych nie mógł wznieść się na wyżyny doskonałości.

Ostatnią kwestią, która wzbudziła wątpliwości Recenzenta, jest podnoszona przeze mnie konieczność przywrócenia należnego miejsca standardom postulowanym i akceptowanym przez staropolską szlachtę. Te standardy były na tyle godne pochwały i na tyle uniwersalne, że jeszcze dziś każdy świadomy obywatel mógłby się pod nimi spokojnie podpisać. Mimo to w świadomości powszechnej negatywny stereotyp szlachty zdecydowanie bierze górę nad rzetelną oceną jej wkładu do państwowej i narodowej aksjologii. Z pewnością nie dotyczy on części naukowców, w obronie których staje Andrzej Klonder. Takie postaci jak Henryk Samsonowicz, Janusz Tazbir, Stanisław Grzybowski, Janusz Ekes i wielu innych bronią się same poprzez swoje publikacje, ale obok nich funkcjonują przecież nieprzejednani krytycy szlacheckich dokonań. Co więcej, te głosy wydają się mieć większą siłę oddziaływania, skoro tak wyraźnie przekładały się na treści podręcznikowe, na wiedzę nauczycieli, a co za tym idzie, także ich uczniów. Oczywiście negatywny stereotyp szlachty jest zjawiskiem dużo bardziej złożonym i nie można wyczerpująco go omówić w tak krótkiej formie wypowiedzi. Sam temat jest jednak na tyle interesujący, że poświęciłam mu odrębny artykuł. Losy tego artykułu dokładnie odzwierciedlają zasygnalizowaną wyżej polaryzację stanowisk. Stąd też w jednych redakcjach spotka1 się z totalną krytyką recenzentów, w innych zaś zdobył najwyższe uznanie. W rezultacie tekst niedługo zostanie opublikowany, a ja zachęcam do lektury.

Kończąc jeszcze raz dziękuję Recenzentowi za wszystkie uwagi, a także za zainteresowanie moją książką. Pozwoliło mi to na wyjaśnienia i być może spowodowało rozwianie niektórych wątpliwości. Każda tego rodzaju opinia pobudza do naukowej dyskusji, do konfrontacji poglądów, a w ślad za tym do nowych wniosków, co jest przecież najwyższą wartością nauki.

Urszula Świderska-Włodarczyk

(Zielona Góra)

\section{BIBLIOGRAFIA}

Górnicki Łukasz. 1954. Dworzanin polski, oprac. R. Pollak, Wrocław.

Tazbir Janusz. 1976. Wzorce osobowe szlachty polskiej w XVII wieku, „Kwartalnik Historii Kultury Materialnej", R. LXXXIII, z. 4, s. 784-797.

Topolski Jerzy. 1977. Gospodarka polska a europejska w XVI-XVIII wieku, Poznań. 
